\title{
Reduction of the nutritional values of diets for hens through supplementation with phytase
}

\author{
Matheus Ramalho de Lima ${ }^{1}$, Fernando Guilherme Perazzo Costa ${ }^{2}$, Patrícia Emília Naves Givisiez², \\ José Humberto Vilar da Silva ${ }^{3}$, Nilva Kazue Sakomura ${ }^{4}$, Denise Fontana Figueiredo Lima ${ }^{5}$ \\ 1 Programa de Pós-graduação em Zootecnia - UFPB. Areia, PB. Bolsista do CNPq. \\ ${ }^{2}$ CCA/UFPB, Areia-PB. Bolsista do CNPq. \\ ${ }^{3}$ CCHSA/UFPB, Bananeiras, PB. Bolsista do CNPq. \\ ${ }^{4}$ UNESP, Jaboticabal, SP \\ 5 UAG/UFRPE, Garanhus, PE.
}

\begin{abstract}
The aim of this work was to evaluate the effects of the reduction on nutritional levels of diets for semiheavy hens during the laying peak on performance, egg quality and bone parameters. A total of eight diets were evaluated, each one with five repetitions of eight birds: 1) control: formulated to supply requirements by the birds; 2) control $+0.03 \%$ or $600 \mathrm{FTU}$; 3) 15\% crude protein; 2,800 kcal ME; 3.8\% Ca and $0.28 \%$ aP; 4) diet $3+0.03 \%$ or $600 \mathrm{FTU}$; 5 ) 14\% crude protein; 2,750 kcal ME; 3.4\% Ca and $0.23 \%$ aP; 6) diet $5+0.03 \%$ or 600 FTU; 7) 13\% crude protein; 2,700 kcal ME; 3.0\% Ca and $0.18 \% \mathrm{aP}$; and 8) diet $7+600 \mathrm{FTU}$. The reduction of the nutritional levels harmed the performance of the birds, particularly egg production and egg mass, which improved by the inclusion of phytase in the diets. However, the parameters for egg quality did not change as the level was reduced down to $15 \%$ crude protein; $2,800 \mathrm{kcal} \mathrm{ME} / \mathrm{kg}$; $3.80 \% \mathrm{Ca}$ and $0.280 \%$ aP, which was not repeated in the levels with lower nutritional density. Reduction of nutritional levels did not affect the evaluated bone parameters, except for resistance, which improved as phytase was added at the level 600 FTU. Reduction on the diet nutritional levels to $15 \%$ crude protein; $2,800 \mathrm{kcal} \mathrm{ME} / \mathrm{kg} ; 3.80 \% \mathrm{Ca}$ and $0.280 \%$ aP with the addition of 600 FTU of phytase does not impair egg production neither egg mass and improve the bone health of birds.
\end{abstract}

Key Words: bone health, eggs, laying hens, performance

\section{Redução do valor nutricional de dietas para poedeiras por meio da suplementação com fitase}

\begin{abstract}
RESUMO - Objetivou-se avaliar os efeitos da redução dos níveis nutricionais de dietas para poedeiras marrons em pico de postura sobre o desempenho das aves, a qualidade dos ovos e os parâmetros ósseos. No total foram avaliadas oito dietas, cada uma com cinco repetições de oito aves: 1. controle: formulada para suprir as exigências das aves; 2) controle + 0,03\% ou $600 \mathrm{FTU}$; 3) 15\% PB; $2.800 \mathrm{kcal}$ de EM; 3,8\% Ca e 0,28\% Pd; 4) dieta 3 + 0,03\% ou $600 \mathrm{FTU}$; 5 ) $14 \%$ PB; $2.750 \mathrm{kcal}$ de EM; 3,4\% Ca e 0,23\% Pd; 6) dieta 5 + 0,03\% ou 600 FTU; 7) 13\% PB; 2.700 kcal de EM; 3,0\% Ca e 0,18\% Pd; e 8) dieta $7+0,03 \%$ ou 600 FTU. A redução dos níveis nutricionais prejudicou o desempenho das aves, principalmente a produção e massa de ovos, que melhorou com a inclusão de fitase nas dietas. Os parâmetros de qualidade dos ovos, no entanto, não se alteraram com a redução até o nível de 15\% de PB; $2.800 \mathrm{kcal}$ de EM/kg; 3,80\% Ca e 0,280\% Pd, o que não se repetiu nos níveis com menor densidade nutricional. Não houve efeito da redução dos níveis nutricionais sobre os parâmetros ósseos avaliados, exceto a resistência, que melhorou com a suplementação de fitase no nível de 600 FTU. A redução nos níveis nutricionais da dieta para 15\% de PB, $2.800 \mathrm{kcal} / \mathrm{kg}$ de EM, 3,8\% de Ca e 0,280\% de Pd com a adição de 600 FTU não prejudica a produção nem a massa de ovos e melhora a saúde óssea das aves.
\end{abstract}

Palavras-chave: desempenho, ovos, poedeiras, saúde óssea

\section{Introduction}

The current poultry industry has been quite effective in reducing production costs, creating products with quality and high biological value for consumers. A major problem in poultry production is the feeding costs, which represent
60 to $70 \%$ of total production costs. In order to reduce it, the focus of this research is to quest for improving efficiency of utilization of the ingredients that constitutes diet formulation within the nutritional requirements for birds.

Much of the phosphorus contained in the raw materials of plant origin used for processing animal feed like grains, 
legumes and even oil seeds, is in an unavailable form to the birds, i.e. in the form of phytic acid or phytate. According to Pandey et al., (2001) these forms are not degraded by monogastric animals such as birds. In addition to phosphorus, phytate leads to another damage to the availability of other nutrients such as calcium, copper, magnesium, iron, manganese and zinc, because when these divalent cations are linked to the phytate they become unavailable (Lehninger et al., 1994). As the birds do not have the capacity to produce endogenous phytase in the speed required to the degradation of phytate, these minerals, and some amino acids are unavailable to the birds because of the excessive presence of phytate in the gastrointestinal tract.

Phytase improves food digestibility (Selle \& Ravidranm, (2007) and enables the reduction of anti-nutritional factors (Campestrini et al., 2005), as phytate and non-starch polysaccharides (Yin et al., 2000), as a result, there is less variation of nutritional quality of the diets, faster complete digestion, lower fecal excretion of nutrients and, consequently, environmental pollution, and a lower incidence of wet feces when the birds are fed high viscosity diets (Bedford., 2000).

Because of the large gap in available phosphorus recommendations for laying hens in the literature and low efficient utilization in the digestive tract of birds (Yu et al., 2004) as well as the factors that affect its absorption, as compared with calcium, this research was proposed in order to evaluate the supplementation of the exogenous phytase in diets with different nutritional density on the performance parameters and quality of eggs and bones of the birds.

\section{Material and Methods}

The experiment was conducted conducted in the Módulo de Pesquisa com Aves do Centro de Ciências Agrárias, Universidade Federal da Paraiba Campus II, Areia. Areia, located in the State of Paraiba, is at coordinates 6 $58^{\prime} 554^{\prime \prime}$ of latitute and $35^{\circ} 43^{\prime} 047^{\prime \prime}$ longitude and 618 meters of altitude.

It was used 320 Bovans Goldline laying hens at 29 weeks of age, distributed in a completely randomized design, in a $4 \times 2$ factorial (four diets with reduced crude protein, metabolizable energy, calcium and available phosphorus; and the presence and absence of phytase) with five replicates of eight birds each. The birds went through a pretrial period of 20 days when egg production was observed in the standardization of the experimental plots. The initial weight of the birds was 1.548 kilograms, with average growth of $3 \%$ in weight in all diets.
Four nutrient levels were set. The first followed the recommendations of Rostagno et al. (2005), while the others (2, 3 and 4) had levels of crude protein, metabolizable energy, calcium and phosphorus reduced. Each nutrition level was supplemented with $0.03 \%$ exogenous phytase, which represented an addition of 600 FTU in the diet, a total of eight diets with and without the addition of the phytase enzyme (Table 1).

It was evaluated the feed intake, production, weight, mass, mass conversion and in dozen of eggs, as performance variables. To assess the egg quality, the specific gravity, the egg yolk pigmentation, the weights of shell, yolk and albumen, the percentages of yolk, shell thickness and albumen, the Haugh units and the total solids of yolk and albumen were analyzed.

At the end of each period, the remains of the rations of each plot were collected to calculate the feed intake. In the last three days of each period, all the eggs of each diet were weighed. The egg production was calculated by dividing the number of eggs per plot by the number of birds corrected for mortality. The egg mass was obtained by the multiplication of the production by weight divided by 100 . The egg mass conversion was calculated by the ratio between feed intake and mass produced and dozen of eggs was calculated by the ratio between feed intake divided by the production, and the quotient was multiplied by twelve. For the determination of specific gravity in saline solution, three eggs per experimental unit was selected every day, while for the determination of yolk, albumen, pigmentation of egg yolk and and their percentages, two different eggs were selected, so there was no change in the internal stability of the egg in evaluation of specific gravity in saline solution.

After egg breaking, which was manually performed, the yolk and albumen of each treatment were separated in 200-mL containers. Right after homogenization with the aid of a glass rod, aliquots of yolk and albumen were taken for analysis of total yolk solids and albumen at $105^{\circ} \mathrm{C}$ for $24 \mathrm{~h}$ cooled to room temperature for 1 hour after weighing. The egg shell analyses were done after drying for 48 hours at room temperature, with thickness of shell assessment.

The shank of the birds were taken, and the left tibias were submitted to test the breaking resistance test and the right ones, after the removal of fat in the "Soxhlet" extractor, were placed in an oven at $600^{\circ} \mathrm{C}$ for four hours (Smith, 1991) to determine the ash of the shank. The bone resistance of the left shank was measured in mechanical press in the Laboratório de Engenharia Civil da Universidade Federal da Paraíba, Campina Grande, Paraíba. The bones were placed 
Table 1 - Food and nutritional composition of the experimental diets

\begin{tabular}{|c|c|c|c|c|c|c|c|c|}
\hline \multirow[t]{2}{*}{ Ingredient } & \multicolumn{8}{|c|}{ Nutritional level } \\
\hline & 1 & 2 & 3 & 4 & 5 & 6 & 7 & 8 \\
\hline Corn & 61.61 & 61.61 & 68.48 & 68.48 & 68.06 & 68.06 & 68.44 & 68.44 \\
\hline Soybean meal & 20.12 & 20.12 & 19.35 & 19.35 & 17.54 & 17.54 & 14.5 & 14.5 \\
\hline Limestone & 9.73 & 9.73 & 9.02 & 9.02 & 8.16 & 8.16 & 7.39 & 7.39 \\
\hline Corn gluten & 3.60 & 3.60 & 0.21 & 0.21 & 0.13 & 0.13 & 0.83 & 0.83 \\
\hline Vegetable oil & 2.14 & 2.14 & 0.00 & 0.00 & 0.15 & 0.15 & 0.00 & 0.00 \\
\hline Dicalcium phosphate & 1.52 & 1.52 & 1.02 & 1.02 & 0.77 & 0.77 & 0.52 & 0.52 \\
\hline Potassium chloride & 0.06 & 0.06 & 0.05 & 0.05 & 0.12 & 0.12 & 0.18 & 0.18 \\
\hline Sodium bicarbonate & 0.36 & 0.36 & 0.36 & 0.36 & 0.44 & 0.44 & 0.52 & 0.52 \\
\hline L-lysine $\mathrm{HCl}$ & 0.19 & 0.19 & 0.11 & 0.11 & 0.04 & 0.04 & 0.00 & 0.00 \\
\hline DL-methionine, 99\% & 0.15 & 0.15 & 0.14 & 0.14 & 0.10 & 0.10 & 0.00 & 0.00 \\
\hline Salt & 0.25 & 0.25 & 0.25 & 0.25 & 0.20 & 0.20 & 0.15 & 0.15 \\
\hline Phytase & 0.00 & 0.03 & 0.00 & 0.03 & 0.00 & 0.03 & 0.00 & 0.03 \\
\hline Chorine chloride & 0.07 & 0.07 & 0.07 & 0.07 & 0.07 & 0.07 & 0.07 & 0.07 \\
\hline Inert $^{3}$ & 0.03 & 0.00 & 0.75 & 0.72 & 4.04 & 4.01 & 7.20 & 7.17 \\
\hline Vitamin $\operatorname{mix}^{1}$ & 0.10 & 0.10 & 0.10 & 0.10 & 0.10 & 0.10 & 0.10 & 0.10 \\
\hline Mineral $\operatorname{mix}^{2}$ & 0.05 & 0.05 & 0.05 & 0.05 & 0.05 & 0.05 & 0.05 & 0.05 \\
\hline $\mathrm{BHT}^{4}$ & 0.01 & 0.01 & 0.01 & 0.01 & 0.01 & 0.01 & 0.01 & 0.01 \\
\hline \multicolumn{9}{|l|}{ Chemical composition } \\
\hline Crude protein $(\%)$ & 17 & 17 & 15 & 15 & 14 & 14 & 13 & 13 \\
\hline Metabolizable energy (kcal/kg) & 2.900 & 2.900 & 2.800 & 2.800 & 2.750 & 2.750 & 2.700 & 2.700 \\
\hline Calcium (\%) & 4.2 & 4.2 & 3.8 & 3.8 & 3.4 & 3.4 & 3.0 & 3.0 \\
\hline Available phosphorus (\%) & 0.375 & 0.375 & 0.280 & 0.280 & 0.230 & 0.230 & 0.180 & 0.180 \\
\hline Lysine (\%) & 0.815 & 0.815 & 0.715 & 0.715 & 0.615 & 0.615 & 0.515 & 0.515 \\
\hline Methionine (\%) & 0.408 & 0.408 & 0.358 & 0.358 & 0.308 & 0.308 & 0.208 & 0.208 \\
\hline Methionine+cistine (\%) & 0.648 & 0.648 & 0.578 & 0.578 & 0.517 & 0.517 & 0.407 & 0.407 \\
\hline Sodium (\%) & 0.23 & 0.23 & 0.23 & 0.23 & 0.23 & 0.23 & 0.23 & 0.23 \\
\hline Potassium (\%) & 0.59 & 0.59 & 0.59 & 0.59 & 0.59 & 0.59 & 0.57 & 0.57 \\
\hline Chloride (\%) & 0.21 & 0.21 & 0.21 & 0.21 & 0.21 & 0.21 & 0.21 & 0.21 \\
\hline Eletrolic balance (mEq/kg) & 191.7 & 191.7 & 191.7 & 191.7 & 191.7 & 191.7 & 186.6 & 186.6 \\
\hline
\end{tabular}

horizontally on two supports, with pressure being applied on their centers. The maximum amount of force applied to the bone before its break was considered as its resistance to breakage (kgf).

Statistical analyses were performed using the program SAEG (UFV, 2007). The diet means were subjected to analysis of variance and compared by the $\mathrm{F}$ test. The significant differences of effects were evaluated by Student Newman Keuls test.

\section{Results and Discussion}

There was no interaction ( $\mathrm{P}>0.05)$ between nutrient levels and phytase for production, weight and egg mass, neither for conversion by egg mass (Table 2).

The nutritional reductions affected production, egg weight, egg mass, and egg mass conversion, so the best results were obtained in the diet with levels that met the needs of hens, i.e. recommended by Rostagno et al. (2005). Egg production and egg mass of the birds with lower nutrient levels up to level 2 (15\% CP, $2800 \mathrm{kcal} / \mathrm{kg}$ of ME, $3.8 \% \mathrm{Ca}$ and $0.280 \%$ of $\mathrm{Pd}$ ) was similar to that of birds with higher nutritional value. The egg weight statistically differed only with the use of diets with lower nutrient supply (13 / 2700 / 3.0 / 0.180). The addition of phytase in the diet significantly improved the egg production and egg mass in 2.37 and $2.15 \%$ respectively, demonstrating the ability of the enzyme in providing more nutrients for the synthesis of products such as eggs.

The results of production and egg mass in relation to the level of available phosphorus were improved with the addition of phytase at $600 \mathrm{FTU}$, which agrees with the results already reported by Wu et al. (2006) when they found an increase in production and egg mass of hens fed deficient-in-P diets ( $0.11 \%$ available $P$ ) supplemented with $300 \mathrm{UF} / \mathrm{kg}$, reaching values similar to those birds fed control $\operatorname{diet}(0.38 \%$ available $\mathrm{P})$.

Unlike the results of this study, Costa et al. (2004), evaluating the available phosphorus levels $(0.235,0.305$ and $0.375 \%)$ and the inclusion of phytase (0; 0.01 and 
Table 2 - Effect of nutrient levels $(\mathrm{N})$ and phytase on egg production, weight, mass and conversion by egg mass

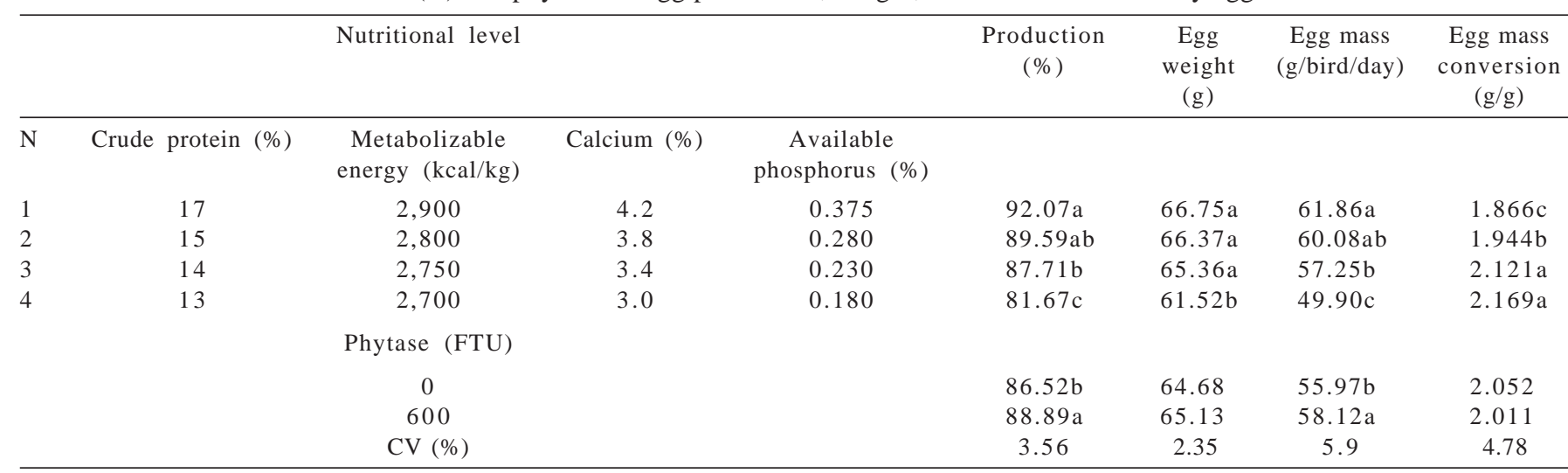

a,b,c - Means in the columns followed by different lower case letters statistically differ by SNK test at 5\% of probability.

$0.02 \%$, which corresponds to 0,500 and 1000 FTU in diets of hens, they found significant effects only for phytase on the feed conversion and no effect in the levels of phosphorus.

Similarly, the results of this study were not confirmed by the work of Snow et al. (2003), who found no effect of phytase supplementation on egg production. Liebert et al. (2005) found the same results for production, however similar effects were observed in this study with regard to egg weight and feed intake.

In this case, the phytase was insufficient to demonstrate any effects on these two last variables, so the data for feed intake are confronted with what Keshavarz (2003) reports, when he comments that there was a reduction in the feed intake when the birds were fed a diet with low levels of available phosphorus which was restored with the enzyme supplementation in the diet.

The intake is increased as the enzyme is supplemented, confirming what was affirmed by Keshayarz (2003). This increase in consumption causes an increased consumption of nutrients, even with the reduction of nutritional density, providing a compensatory gain to this reduction, enabling a higher intake of nutrients by the birds.
In contrast, Wu et al. (2006) comments on his findings that the reduction of available phosphorus in the diet caused a reduction in feed intake, but when phytase was added to the experimental diets, consumption was improved, although it had been placed below the control diet.

There was interaction $(\mathrm{P}<0.05)$ between nutrient levels and phytase in the diet to feed intake and dozen of eggs (Table 3). Comparing the performance between the birds fed the same nutritional level, the addition of phytase in these diets did not change neither the feed intake nor the dozen of eggs.

There was no influence of nutrient levels on the feed intake of hens fed diets without phytase. However, when comparing the effect of nutrient levels in diets with the addition of phytase, it was found greater feed intake in birds fed diets with higher nutrient density.

Silva et al. (2008) using 300 FTUof phytase supplemented in the diet of hens found no significant differences in food consumption. Accordingly, Boling et al. (2000) and Liebert et al. (2005) also reported no effect of phytase supplementation on this variable.

Table 3 - Feed intake and conversion to a dozen of eggs of semi-heavy hens

\begin{tabular}{|c|c|c|c|c|c|c|c|c|}
\hline \multirow[b]{3}{*}{$\mathrm{N}$} & \multirow[b]{3}{*}{ Crude protein (\%) } & \multirow{3}{*}{$\begin{array}{c}\text { Nutritional level } \\
\text { Metabolizable } \\
\text { energy }(\mathrm{kcal} / \mathrm{kg})\end{array}$} & \multirow[b]{3}{*}{ Calcium (\%) } & \multirow[b]{3}{*}{$\begin{array}{c}\text { Available } \\
\text { phosphorus (\%) }\end{array}$} & \multicolumn{2}{|c|}{$\begin{array}{l}\text { Feed intake } \\
\text { (g/bird/day) }\end{array}$} & \multicolumn{2}{|c|}{$\begin{array}{l}\text { Dozen of eggs } \\
\quad(\mathrm{kg} / \mathrm{dz})\end{array}$} \\
\hline & & & & & \multicolumn{2}{|c|}{ Phytase (FTU) } & \multicolumn{2}{|c|}{ Phytase (FTU) } \\
\hline & & & & & 0 & 600 & 0 & 600 \\
\hline 1 & 17 & 2,900 & 4.2 & 0.375 & 113.54 & $112.86 a$ & $1,405 \mathrm{Ac}$ & $1,379 \mathrm{Bb}$ \\
\hline 2 & 15 & 2,800 & 3.8 & 0.280 & 113.24 & $114.51 \mathrm{a}$ & $1,426 \mathrm{Abc}$ & $1,514 \mathrm{Bab}$ \\
\hline 3 & 14 & 2,750 & 3.4 & 0.230 & 112.26 & $112.30 \mathrm{ab}$ & $1,565 a b$ & $1,534 \mathrm{a}$ \\
\hline \multirow[t]{2}{*}{4} & 13 & 2,700 & 3.0 & 0.180 & $112.32 \mathrm{~A}$ & $108.20 \mathrm{Bb}$ & $1,662 \mathrm{Aa}$ & $1,527 \mathrm{Ba}$ \\
\hline & & CV (\%) & & & \multicolumn{2}{|c|}{1.93} & \multicolumn{2}{|c|}{4.66} \\
\hline
\end{tabular}

a,b,c - Means in the column followed by different lower case letters statistically differ by SNK test at 5\% of probability.

A,B,C - Means in the line followed by different upper case letters statistically differ by SNK test at $5 \%$ of probability. 
This increased feed intake of birds fed diets with higher levels of nutrients is explained by the addition of enzyme therefore showing a better performance. This is possibly because of the increased consumption of nutrients due to a possible increase in digestibility caused by the enzyme (Selle \& Ravidran, 2007), which would generate a greater availability of nutrients in the body of the bird consequently producing better zootechnical results in the evaluated variables.

The nutrient levels of the diet influenced the dozen of eggs in both diets, with or without the use of phytase. In diets with the enzyme, it was seen the worst conversion from the nutritional reduction to $14 \% \mathrm{CP}, 2,750 \mathrm{kcal} / \mathrm{kg}$ of ME, 3.4\% Ca and $0.230 \% \mathrm{Pd}$, while without phytase, the worst conversion was observed with $13 \%$ CP, 2,700 kcal $/ \mathrm{kg}$ of ME, 3.0\% Ca and $0.180 \%$ of Pd. Comparing the nutrient levels and supplementation of phytase, this provided an improvement of dozen of eggs at all evaluated levels. These data show that the nutritional density of the diets can be much smaller when there is the supplementation of phytase enzyme in relation to this variable, which undoubtedly represents a larger number of dozens of eggs for feed intake. Also because these results confirm the other variables, such as production and egg mass, which were improved when phytase was added to the diet and finally because it validates and confirms the efficiency of the enzyme to degrade phytate in vegetables and efficiently provide the nutrients that once could not be assimilated by the hens. Silva et al. (2008), in research on semi-heavy brown hens during the first cycle of production, also observed a significant improvement in feed conversion per dozen of eggs with the addition of 600 units of phytase.

The amount of eggs from hens was influenced only by reductions in nutritional levels $(\mathrm{P}<0.05)$, also changing $(\mathrm{P}<0.05)$ some variables related to the internal and external quality of eggs (Table 4).
There was no significant difference for the variable specific gravity and weight of the egg yolk of hens, on nutritional levels neither for levels of phytase. However, the weight of the albumen was influenced by the diets, as well as shell weight and Haugh unit.

The specific gravity was not affected by the treatments. Boling et al. (2000) also found no significant differences in specific gravity of eggs of hens from 20 to 60 weeks of age fed $0.10 \%$ available phosphorus and 300 FTU of phytase/kg in the ration. The nutrient levels in the diet significantly influenced the Haugh unit, and the values improved as it reduced the supply of $\mathrm{CP}, \mathrm{ME}, \mathrm{Ca}$ and $\mathrm{P}$ in the diets.

The weight of albumen was better in the diet that met the daily needs of birds (17\% CP, $2900 \mathrm{kcal} / \mathrm{kg}$ of ME, $4.2 \%$ $\mathrm{Ca}, 0.375 \% \mathrm{Pd}$ ) in accordance with the recommendations of Rostagno et al. (2005), not differing from the subsequent diet (15\% CP, $2800 \mathrm{kcal} / \mathrm{kg}$ of ME, 3.8\% Ca, $0.280 \%$ of Pd). However, the eggs of poultry fed lower levels of nutrients (13\% CP, $2700 \mathrm{kcal} / \mathrm{kg}$ of ME, 3.0\% Ca, $0.180 \% \mathrm{Pd}$ ) showed $(\mathrm{P}<0.05)$ lower albumen weight.

When the birds were fed diets formulated to meet their requirements, the eggshell showed a higher weight, but it did not statistically differ from those that received nutritional reduction of $15 \% \mathrm{CP}, 2,800 \mathrm{kcal} / \mathrm{ME}, 3.8 \%$ and $0.280 \%$ Pd. From these nutritional values, a decrease of weight of eggshell was verified. Pereira (2004) reported that birds fed normal levels of calcium presented greater weight of shells than those fed lower levels, confirming the results found in this study. This effect had been known for a while because of the results found by Outerhout (1980), Farmer et al. (1986) and Clunies et al. (1992 a, b) which had already reported this effect of shell weight in relation to the level of calcium in the diet.

The percentage of shell of eggs was higher because of a lighter weight of produced eggs, thus the weight of the

Table 4 - Specific gravity, weight of albumen, shell, yolk and Haugh unit of eggs

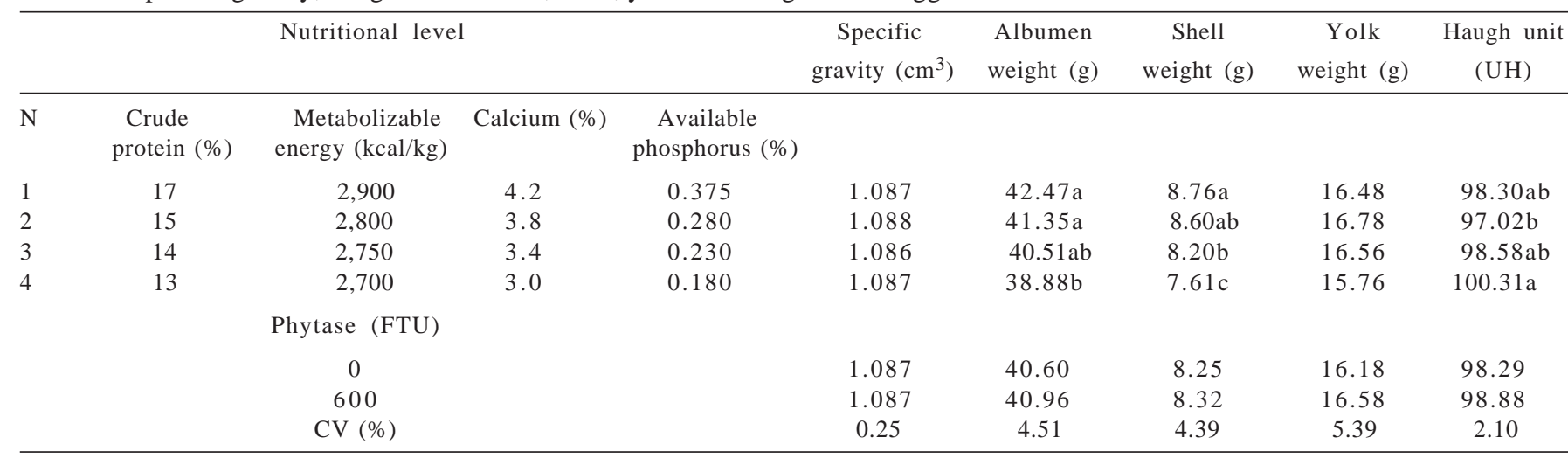

a,b,c - Means in the column followed by different lower case letters statistically differ by SNK test at $5 \%$ of probability. 
shells was higher due the lower $(\mathrm{P}<0.05)$ egg weight compared to other diets, i.e., the recommendation of Rostagno et al. (2005) and subsequent diet (15\% CP, 2,800 kcal/kg of ME, $3.8 \% \mathrm{Ca}$ and $0.280 \% \mathrm{Pd}$ ), so that, although there might have been an increased activity of $1.25\left(\mathrm{OH}_{2}\right) \mathrm{D} 3$ (Ligeiro, 2007) by reducing the level of phosphorus, it was not enough to increase the weight of the shells, caused maybe due to the low level of calcium in the diets with lower nutrient density.

Even with the trend of increasing activity of the hormone $1.25\left(\mathrm{OH}_{2}\right)$ D3 with deficient-in-phosphorus diets (Ligeiro et al., 2007), which would lead to a higher indirect absorption of calcium in the enterocytes, it was not sufficient for effective improvements in the weight of eggshell, possibly due to the low levels of calcium used, so these results show that the hormone increases the possibility of calcium absorption in the small intestine and not in its absorption because it depends on amount of dissolved calcium in the digestion.

There was no significant effect $(\mathrm{P}>0.05)$ for the percentages of albumen, yolk and shell, shell thickness and yolk solids. Nevertheless, albumen solids were affected by diets $(\mathrm{P}<0.05)$ with the lowest value obtained in eggs of birds receiving the highest nutrient reduction (13\% CP, 2,700 kcal ME / kg, 3.0\% Ca and 0.180\% Pd) (Table 5).

Lim et al. (2003) working with hens from 21 to 41 weeks of age, found that supplementation of 300 FTU phytase/ $\mathrm{kg}$ diet improved the egg shell quality by reducing the number of broken eggs and soft shell. The authors also observed that the effect of phytase supplementation is significantly modified by the levels of $\mathrm{Ca}$ and $\mathrm{Pd}$, in which the lowest levels of calcium, phytase proves to be more efficient. However, this study found no differences $(\mathrm{P}>0.05)$ regarded to egg shell quality, such as specific gravity, but there was a reduction $(\mathrm{P}<0.05)$ of the total solids present in the egg albumen as they lowered the nutritional density of diets.

There was no significant differences for the variables assessed in the bones of birds for nutritional levels, however phytase improved $(\mathrm{P}<0.05)$ bone resistance (Table 6).

A similar result was reported by Waldroup et al. (2000) with the addition of $800 \mathrm{FTU}$ in rations of hens from 1 to 21 days of age. Onyango et al. (2003) also found a high correlation between the level of available $P$ in the feed and the ash content in the shank of broiler chicks from 1 to 21 days of age. Similarly, Silva et al. (2008) evaluated the phytase on increasing levels of available phosphorus in the diet of laying hens and confirmed that the enzyme enhances the bone strength of the birds with the addition of phytase.

Despite of not being a significant difference, ash, calcium and phosphorus were reduced as the nutritional density was decreased. Silva et al. (2008) also reported an increase in resistance of bone to break when the ash content of the shank of hens increased, confirming the results of this study.

The results on the levels of ash and breaking resistance of the shank of birds show the importance, especially of dietary phosphorus, on the bone parameters, so that a reduction of its levels damages ash and endurance, confirming the results found by Silva et al. (2008) when reported that there was an increasing linear effect of available phosphorus in the ashes and breaking resistance of shank of hens, indicating the importance of phosphorus for bone parameters of birds.

Table 5 - Percentages of albumen, shell, yolk, shell thickness and yolk and albumen total solids of eggs of the experimental birds

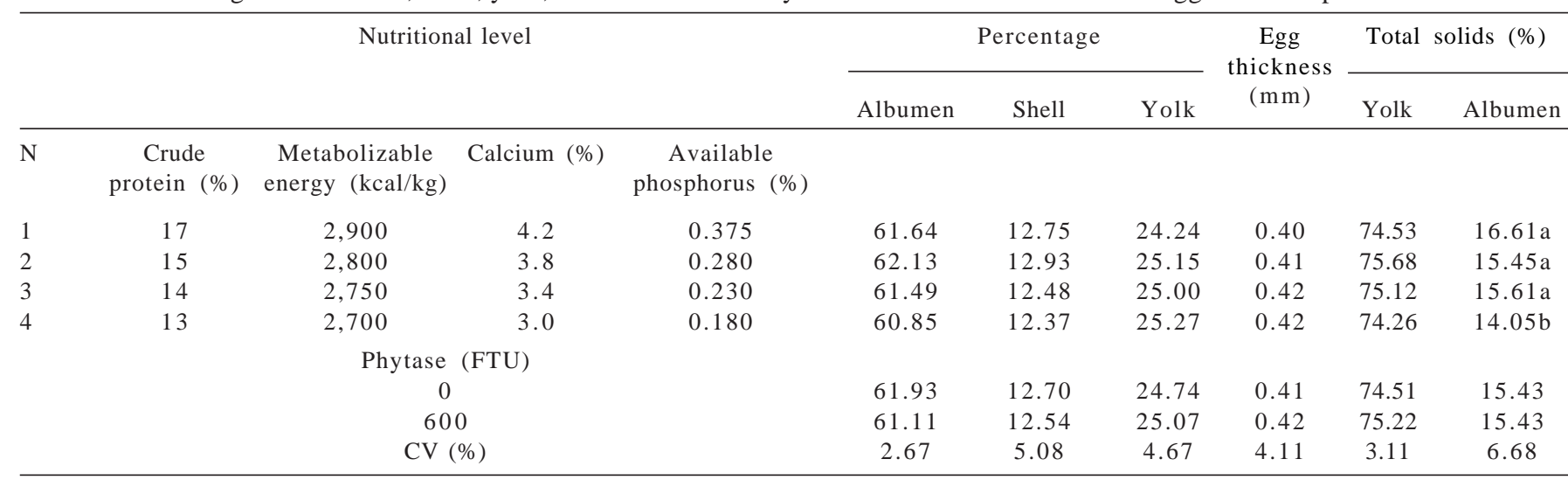

a,b,c - Means in the columns followed by different lower case letters statistically differ by SNK test at 5\% of probability. 
Table 6 - Ash content, calcium and phosphorus, and the break resistance

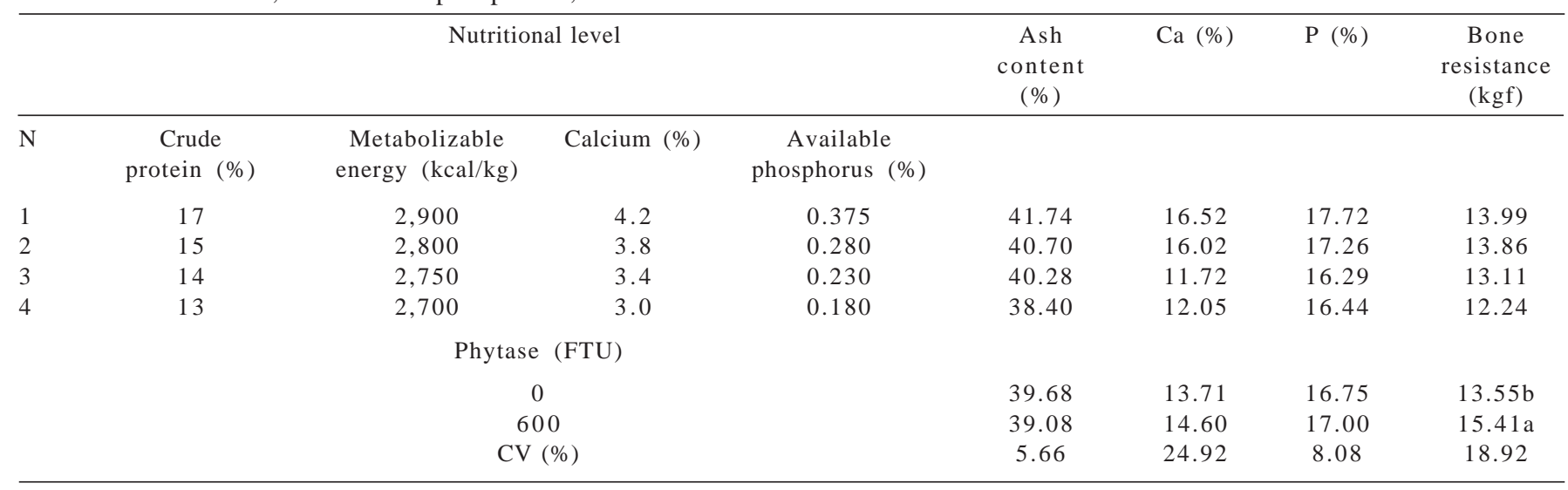

a,b,c - Means in the columns followed by different lower case letters statistically differ by SNK test at 5\% of probability.

\section{Conclusions}

Reduction of nutritional levels from $17 \%$ of CP; $2,900 \mathrm{kcal} \mathrm{ME} / \mathrm{kg} ; 4.2 \% \mathrm{Ca}$ and $0.375 \%$ aP to $15 \%$ of CP; $2,800 \mathrm{kcal} \mathrm{ME} / \mathrm{kg} ; 3.80 \% \mathrm{Ca}$ and $0.280 \%$ aP with the addition of 600 FTU of phytase does not impair the egg production and egg mass and improve the bone health of birds.

\section{References}

BEDFORD, M.R. Exogenous enzymes in monogastric nutrition their current value and future benefits. Animal Feed Science and Technology, v.86, p.1-13, 2000.

BOLING, S.D.; DOUGLAS, M.W.; JONSON, M.L. et al. The effects of dietary available phosphorus levels and phytase on performance of young and older laying hens. Poultry Science, v.79, n.2, p.224-230, 2000.

CLUNIES, M.; EMSLIE. J.; CHENG, T.K. et al. Sensitivity of various parameters of laying hens. Poultry Science, v.69, n.12, 2009-2013, 1990a.

CLUNIES, M.; PARKS, D.; LEESON, S. Calcium and phosphorus metabolism and eggshell formation of hens different amount of calcium. Poultry Science, v.71, n.3.p.482-89, 1992b.

COSTA, F.G.P.; JACOME, I.M.T.D.; SILVA, J.H.V. et al. Níveis de fósforo disponível e de fitase na dieta de poedeiras de ovos de casca marrom. Ciência Animal Brasileira, v.5, n.2, p.73-81, 2004.

FARMER, M.; ROLAND SR., D.; CLARK, A.J. Influence of diatary calcium on bone calcium utilization. Poultry Science, v.65.p337-44.1986.

KESHAVARZ, K. The effect of different levels of nonphytate phosphorus with and without phytase on the performance of four strains of laying hens. Poultry Science, v.82, p.71-91, 2003.

LEHNINGER, A.L. Princípios da bioquímica. São Paulo: Sarvie, 1994.

LIEBERT, F.; HTOO, J.K.; SÜNDER, A. Performance and nutrient utilization of laying hens fed low-phosphorus corn-soybean and wheat soybean diets supplemented with microbial phytase. Poultry Science, v.84, p.1576-1583, 2005.
ONYANGO, E.M.; HESTER, P.Y.; STROSHINE, R. et al. Bone densitometry as an indicator of percentage tibia ash in broiler chicks fed varying calcium and phosphorus levels. Poultry Science, v.82, p.1787-1791, 2003.

OUSTERHOUT, L.E. Effects of calcium and phosphorus levels on egg weight and egg Shell quality in laying hens. Journal of Poultry Science, v.59, n.7, p.1480-1484, 1980.

PANDEY, A.; SZAKACS, G.; SOCCOL, C.R. et al. Production, purification and properties of microbial phytases. Bioresource Technology, v.77, n.3, p.203-214, 2001.

ROSTAGNO, H.S.; ALBINO, L.F.T.; DONZELE, J.L. et al. Tabelas brasileiras de exigências nutricionais para aves e suínos (Composição de alimentos e exigências nutricionais). Viçosa, MG: UFV, 2005. 141p.

UNIVERSIDADE FEDERAL DE VIÇOSA - UFV. SAEG - Sistema para Análises Estatísticas, Versão 7.1. Viçosa: FUNARBE, 2000. 150p. [Manual do Usuário].

SELLE, P.H.; RAVIDRAN, V. Microbial phytase in poultry nutrition: review. Animal Feed Science and Technology, v.135, p.1-41, 2007.

SILVA, J.H.V.; ARAÚJO, J.A.; GOULART, C.C. et al. Influência da interação fósforo disponível $\mathrm{x}$ fitase da dieta sobre $\mathrm{o}$ desempenho, os níveis plasmáticos de fósforo e os parâmetros ósseos de poedeiras comerciais. Revista Brasileira de Zootecnia, v.37, n.12, p.2157-2165, 2008.

SNOW, J.L.; DOUGLAS, M.W.; PARSONS, C.M. Phytase effects on amino acid digestibility in molted laying hens. Poultry Science, v.82, p.474-477, 2003.

WALDROUP, P.W.; KERSEY, J.H.; SALEH, E.A. et al. Nonphytate phosphorus requirement and phosphorus excretion of broiler chicks fed diets composed of normal or high available phosphate corn with and without microbial phytase. Poultry Science, v.79, p.1451-1459, 2000.

WU, G.; LIU, Z.; BRYANT, M.M.; ROLAND SR., D.A. Comparison of Natuphos and Phyzyme as phytase sources for commercial layers fed corn-soy diet. Poultry Science, v.85, p.64-69, 2006.

YIN, Y.-L.; MCEVOY, J.D.G.; SCHULZE, H. Apparent digestibility (ileal and overall) of nutrients and endogenous nitrogen losses in growing pigs fed wheat (var. Soissons) or its by-products without or with xylanase supplementation. Livestock Production Science, v.62, p.119-132, 2000.

YU, B.; JAN, Y.C.; CHUNG, T.K. et al. Exogenous phytase activity in the gastrointestinal tract of broiler chickens. Animal Feed Science and Tecnhnology, v.117, p.295-303, 2004. 